\title{
Deinococcus radiodurans engineered for complete toluene degradation facilitates $\mathrm{Cr}(\mathrm{VI})$ reduction
}

\author{
Correspondence \\ Michael J. Daly \\ mdaly@usuhs.mil \\ Hassan Brim \\ hbrim@howard.edu
}

Received 17 March 2006

Revised 8 May 2006

Accepted 8 May 2006

\author{
Hassan Brim, ${ }^{1}$ Jeffrey P. Osborne, ${ }^{2}$ Heather M. Kostandarithes, ${ }^{3}$ \\ James K. Fredrickson, ${ }^{3}$ Lawrence P. Wackett ${ }^{4}$ and Michael J. Daly ${ }^{5}$ \\ ${ }^{1}$ Department of Microbiology and Cancer Center, Howard University, 2041 Georgia Avenue \\ N.W., Washington, DC 20060, USA \\ ${ }^{2}$ Department of Chemistry, Manchester College, North Manchester, IN 46962, USA \\ ${ }^{3}$ Biological Sciences Division, Pacific Northwest National Laboratory, Richland, WA 99352, \\ USA \\ ${ }^{4}$ Department of Biochemistry, University of Minnesota, St Paul, MN 55108, USA \\ ${ }^{5}$ Department of Pathology, Uniformed Services University of the Health Sciences(USUHS), \\ Rm B3153, 4301 Jones Bridge Road, Bethesda, MD 20814, USA
}

\begin{abstract}
Toluene and other fuel hydrocarbons are commonly found in association with radionuclides at numerous US Department of Energy sites, frequently occurring together with $\mathrm{Cr}(\mathrm{VI})$ and other heavy metals. In this study, the extremely radiation-resistant bacterium Deinococcus radiodurans, which naturally reduces $\mathrm{Cr}(\mathrm{VI})$ to the less mobile and less toxic $\mathrm{Cr}(\mathrm{III})$, was engineered for complete toluene degradation by cloned expression of tod and $x y /$ genes of Pseudomonas putida. The recombinant Tod/Xyl strain showed incorporation of carbon from ${ }^{14} \mathrm{C}$-labelled toluene into cellular macromolecules and carbon dioxide, in the absence or presence of chronic ionizing radiation. The engineered bacteria were able to oxidize toluene under both minimal and complex nutrient conditions, and recombinant cells reduced $\mathrm{Cr}(\mathrm{VI})$ in sediment microcosms. As such, the Tod/Xyl strain could provide a model for examining the reduction of metals coupled to organic contaminant oxidation in aerobic radionuclide-contaminated sediments.
\end{abstract}

\section{INTRODUCTION}

Contamination at US Department of Energy (DOE) waste sites comprises large inventories of organic, inorganic and radionuclide contaminants in the soil and vadose zones. The contamination is a result of past disposal of wastes directly to cribs and trenches, and also of leaking waste storage tanks (Macilwain, 1996; Riley et al., 1992). The most common contaminants that have been found in combination in soils include: radionuclides, such as uranium, strontium and caesium; heavy metals, such as chromium, lead and mercury (Lovley \& Coates, 1997; McCullough et al., 2003); the fuel hydrocarbons benzene, toluene, ethylbenzene and xylenes (BTEX); and chlorinated hydrocarbons, such as trichloroethylene and polychlorinated biphenyls (Riley et al., 1992). Metal reduction/immobilization and toxic organic compound degradation, carried out by metabolically active bacteria close to sources of contamination, where radionuclide concentrations can be very high, could prevent or minimize dissemination of contaminants before they become widely dispersed in the environment. For bioremediation to be

Abbreviations: BTEX, benzene, toluene, ethylbenzene and xylenes; DOE, US Department of Energy; TDO, toluene dioxygenase. effective in such areas, micro-organisms must be able to withstand cellular toxicity caused by heavy metals, solvents and chronic ionizing radiation. These requirements have not been met by any single known organism, nor are they likely to be achieved in the foreseeable future by engineering genetic components of radiation resistance into other bacteria that are radiation sensitive (Daly, 2000; Daly et al., 2004; Ghosal et al., 2005; Saier, 2005). Therefore, our approach has been to express cloned genes in the naturally radiation-resistant Deinococcus bacteria, extending their intrinsic metabolic functions (Brim et al., 2000, 2003; Lange et al., 1998).

Deinococcus radiodurans strain R1 (ATCC BAA-816) is the most well-characterized member of the radiation-resistant bacterial family Deinococcaceae (Makarova et al., 2001; Omelchenko et al., 2005). It is non-pathogenic, amenable to genetic engineering and historically best known for its extreme resistance to gamma radiation (Brim et al., 2003; Daly \& Minton, 1996; Daly, 2000; Daly et al., 2004; Ghosal et al., 2005; Lange et al., 1998). Under complex nutrient conditions, the bacteria can grow and functionally express cloned foreign genes in the presence of $60 \mathrm{~Gy} \mathrm{~h}^{-1}$ (Brim et al., 2000; Daly, 2000; Lange et al., 1998). These 
characteristics were the impetus for its genomic sequencing and annotation (White et al., 1999), global proteome and transcriptome analyses (Lipton et al., 2002; Liu et al., 2003), and ongoing development for bioremediation (Brim et al., 2000; Daly, 2000; Lange et al., 1998). The isolation of $D$. radiodurans from highly radioactive sediments beneath a waste tank located on the DOE Hanford Site that had leaked high-level radioactive waste $\{$ depth, $84 \mathrm{ft}(25.60 \mathrm{~m}) ; 21 \mu \mathrm{Ci}$ $(777 \mathrm{kBq}){ }^{137} \mathrm{Cs}\left[\gamma, \beta^{-}\right]^{\mathrm{E}}(\mathrm{g} \text { soil })^{-1}$; Fredrickson et al., 2004$\}$ underscores the potential in further developing this species as described here.

Toluene, a fuel hydrocarbon, is a contaminant in hundreds of DOE mixed waste sites (Riley et al., 1992). This contaminant is a growth substrate for a number of organisms, including Pseudomonas putida strains F1 and mt-2, for which the genetics and biochemistry have been studied in great detail (Aemprapa \& William, 1998; Harayama \& Rekik, 1990; Horn et al., 1991; Timmis et al., 1994; Wackett et al., 1994; Zylstra \& Gibson, 1989). However, P. putida is extremely sensitive to ionizing radiation (Daly, 2000; Daly et al., 2004). P. putida $\mathrm{F} 1$ and $\mathrm{mt}-2$ express tod and xylgenes, respectively, for the catabolism of fuel-derived aromatic hydrocarbons, and they represent two of the most proficient toluene-degrading micro-organisms yet reported. With respect to $P$. putida genes encoding degradation of toluene, our goal has been to construct a pathway in $D$. radiodurans that allows it to completely degrade this solvent. We note that growth of $D$. radiodurans in radioactive environments is dependent on the presence of a rich source of EmbdenMeyerhof-Parnas substrates (e.g. fructose, glucose and maltose) and amino acids (Venkateswaran et al., 2000). Thus, our objective, with respect to remediation of toxic metals and organic compounds at radioactive DOE waste sites, has been to expand the repertoire of metabolic functions of $D$. radiodurans under nutrient-rich biostimulated conditions (Venkateswaran et al., 2000).

We previously reported that cultures of wild-type $D$. radiodurans can reduce $\mathrm{Cr}(\mathrm{VI})$ to the less mobile and less toxic $\mathrm{Cr}$ (III) oxidation state (Eary \& Rai, 1987; Fredrickson et al., 2000). $\mathrm{Cr}(\mathrm{VI})$ is a known human carcinogen, but its reduction to $\mathrm{Cr}$ (III) renders the metal non-mutagenic and non-carcinogenic (Sugden et al., 2001). Constructing a $D$. radiodurans strain capable of mineralizing toluene and using energy derived from toluene catabolism to help fuel native (Fredrickson et al., 2000) or cloned (Brim et al., 2000) metal-reducing functions could be useful in remediating many radioactive waste sites. With this goal in mind, we cloned genes of the P. putida tod and $x y l$ operons into $D$. radiodurans and evaluated the toluene-degrading and $\mathrm{Cr}(\mathrm{VI})$-reducing capabilities of the engineered strain in minimal and rich nutrient medium, and in uncontaminated sediment samples obtained from the DOE Hanford Site, amended with toluene and/or $\mathrm{Cr}(\mathrm{VI})$. We report that $D$. radiodurans expressing $P$. putida tod and $x y l$ operons is capable of mineralizing toluene and other fuel hydrocarbons, and that energy derived from toluene catabolism is coupled to its native $\mathrm{Cr}(\mathrm{VI})$-reducing capabilities (Fredrickson et al., 2000).

\section{METHODS}

D. radiodurans engineering strategy. The entire $D$. radiodurans strain R1 (ATCC BAA-816) genomic DNA sequence (White et al., 1999) was searched for similarity to the P. putida tod and $x y l$ sequences using BLAST. With the exception of a homologue of $x y l J$ in D. radiodurans (DRA0122) (38\% amino acid identity), no sequences were found to have significant similarity, either as DNA or as translated peptides, with todC1,C2, B, A,D and $E$, and $x y l F, Q$ and $K$. The integration vector pMD417 contains a $4 \mathrm{kbp} D$. radiodurans chromosomal segment ( $b c$, Fig. 1), which contains a constitutively expressed deinococcal promoter (Daly \& Minton, 1996). The bc segment allows the vector to recombine by a single crossover into the targeted $D$. radiodurans S11 chromosome sequence (Brim et al., 2000; Daly \& Minton, 1996) located on the $2 \cdot 8 \mathrm{Mbp}$ chromosome (Chromosome I) (White et al., 1999; Brim et al., 2000). Upon integration, sequences cloned within pMD417 become flanked by $4 \mathrm{kbp}$ $b c$ repeats. pMD858 (Fig. 1) is the product of cloning a $6 \mathrm{kbp}$ EcoRI-NdeI (converted to BamHI) fragment of pDTG351 (Horn et al., 1991), containing todC1C2BADE, into the EcoRI-BamHI site of pMD417K, which encodes $\mathrm{Km}$ resistance. Transformation of pMD858 into strain R1 with $\mathrm{Km}$ selection yielded MD859. pMD864 (Fig. 1) is the product of cloning the $5.5 \mathrm{kbp}$ Xhol fragment (containing $x y l F J Q K$ ) from pTS66 (Harayama \& Rekik, 1990) into the EcoRI-BamHI site of pMD417C, which encodes $\mathrm{Cm}$ resistance. Transformation of pMD864 into strain R1 with Cm selection yielded MD883. Southern analysis with radiolabelled probes confirmed the predicted integration structures of MD859 and MD883, and the adjacent integration of the tod and $x y l$ cassettes, in strain MD884 (Fig. 1c).

Toluene degradation by $D$. radiodurans under non-growth conditions (resting cells). D. radiodurans was initially grown in TYF broth $[1 \%$ Bacto Tryptone (Difco), $0.5 \%$ yeast extract and $0 \cdot 2 \%$ fructose] and P. putida F1 was grown in L broth (with $0 \cdot 1 \%$ glucose; Hugouvieux-Cotte-Pattat et al., 1990). Both strains were grown to mid-exponential phase $\left(\mathrm{OD}_{600} 0 \cdot 5\right.$; approx. $1 \times 10^{8}$ cells $\left.\mathrm{ml}^{-1}\right)$. Cells were then centrifuged and washed three times with $25 \mathrm{mM}$ sodium phosphate buffer, $\mathrm{pH} 7 \cdot 2$, containing $0 \cdot 2 \%$ fructose, and resuspended in $25 \mathrm{mM}$ potassium phosphate, $\mathrm{pH} 7 \cdot 2$, con-

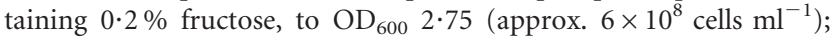
these cells were termed 'resting cells'. Resting cells cannot grow because of the absence of amino acids and essential micronutrients (Venkateswaran et al., 2000). Resting cells (10 ml; $\left.\mathrm{OD}_{600} 2 \cdot 75\right)$ were placed in sterile $250 \mathrm{ml}$ biometers and $3 \mathrm{ml} 1 \mathrm{M} \mathrm{NaOH}$ was added to each sidearm. Then, $250 \mu \mathrm{l}$ [ring-UL- ${ }^{14} \mathrm{C}$ ] toluene [specific activity $56 \cdot 2 \mu \mathrm{Ci} \mu \mathrm{mol}^{-1}\left(2 \cdot 08 \mathrm{MBq} \mu \mathrm{mol}^{-1}\right) ; 378 \mu \mathrm{M}$ in $N, N$-dimethylformamide] was added to the cells in the biometer. The final concentration of [ring-UL- $\left.{ }^{14} \mathrm{C}\right]$ toluene was $9 \cdot 22 \mu \mathrm{M}$. At various time intervals, an aliquot of the $\mathrm{NaOH}$ solution containing trapped $\mathrm{CO}_{2}$ was transferred to a scintillation vial, purged vigorously for $2 \mathrm{~min}$ (in controls, this has been found to be sufficient to remove residual toluene) and mixed with $15 \mathrm{ml}$ EcoLume scintillation fluid. After $12 \mathrm{~h}$ in the dark, a sample was removed and radioactivity was measured using a Beckman LS 3801 scintillation counter. A $25 \mu \mathrm{l}$ volume of cell suspension was removed from the biometer and spotted onto a $1 \times 1 \mathrm{~cm}$ silica TLC plate (see below). After drying, the plate was placed in a scintillation vial, along with $5 \mathrm{ml}$ EcoLume, and non-volatile radioactivity was measured. The cells were pelleted at $4350 \mathrm{~g}$ for $10 \mathrm{~min}$ at $4{ }^{\circ} \mathrm{C}$ and washed three times with ice-cold $0.85 \% \mathrm{NaCl}$. Fractionation into cellular components was accomplished as described by others (Hanson \& Phillips, 1981). 
(a)

Toluene

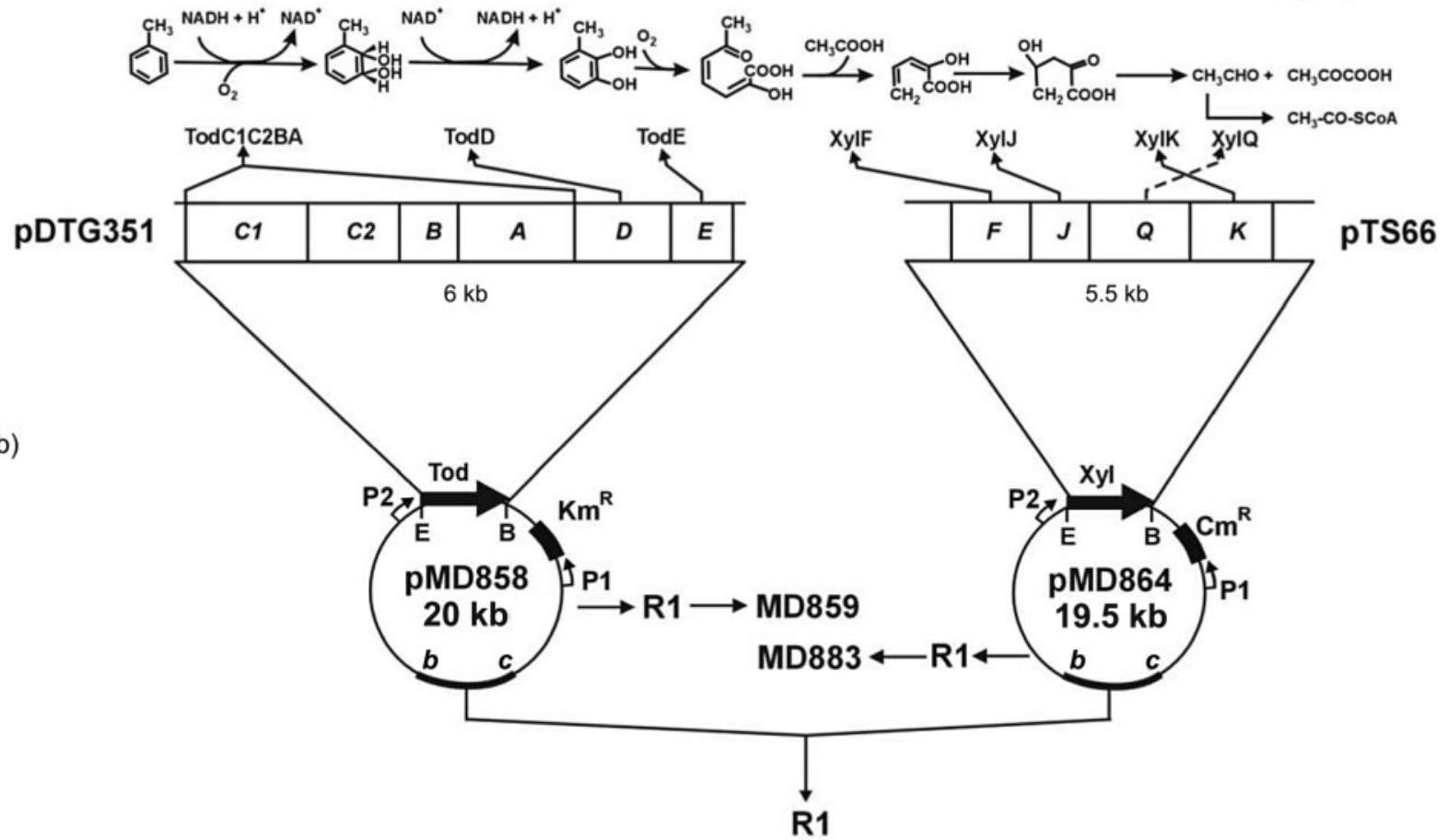

(c)

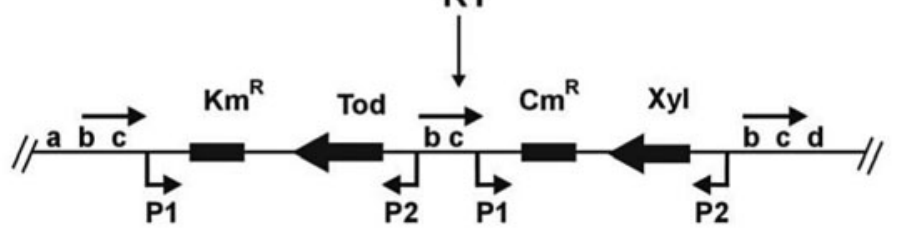

MD884

Fig. 1. Construction of toluene-mineralizing $D$. radiodurans. (a) Intermediates of toluene degradation encoded by the indicated genes. (b) Co-integration of the tod and $x y l$ gene cassettes into $D$. radiodurans involved the construction of two different plasmids derived from the tandem duplication vector pMD417. Both constructions placed the two degradation cassettes downstream of a constitutively expressed promoter P2 that is distinct from the constitutive P1 promoter upstream of the resistance genes for $\mathrm{Km}\left(\mathrm{Km}^{\mathrm{R}}\right)$ and $\mathrm{Cm}\left(\mathrm{Cm}^{\mathrm{R}}\right)$. (c) Co-transformation of pMD858 and pMD864 into strain R1 with double $\mathrm{Km}$ and $\mathrm{Cm}$ selection yielded strain MD884. R1, D. radiodurans strain R1 (ATCC BAA-816).

Toluene degradation by $D$. radiodurans under growth conditions (rich medium). Two $20 \mathrm{ml}$ vials were suspended using copper wire inside a 11 glass bottle, which was closed with a butyl rubber septum. Stainless steel needles [8 in $(20 \cdot 32 \mathrm{~cm}), 22$ gauge], connected to two-way stainless-steel Luer-lock valves, were fitted so that they passed through the septum and into the suspended vials. After autoclaving the outfitted bottle, $6 \mathrm{ml}$ TYF broth, containing $250 \mu \mathrm{M}$ toluene and $4 \cdot 5 \mu \mathrm{M}$ [ring-UL- ${ }^{14} \mathrm{C}$ ] toluene [specific activity $\left.56 \cdot 2 \mu \mathrm{Ci} \mu \mathrm{mol}^{-1}\left(2 \cdot 08 \mathrm{MBq} \mu \mathrm{mol}^{-1}\right)\right]$, was inoculated with MD884

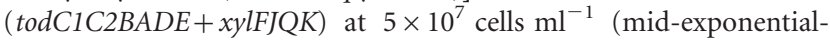
phase cells grown in TYF to $\operatorname{OD}_{600} 0 \cdot 5$ ) and added to one vial via its needle. A $1 \mathrm{ml}$ volume of $2 \mathrm{M} \mathrm{NaOH}$ was added to the other vial in the same manner. The flask was incubated at $32^{\circ} \mathrm{C}$, at 200 r.p.m., to early stationary phase $\left(\mathrm{OD}_{600} 1 \cdot 0\right.$; approx. $\left.2 \times 10^{8} \mathrm{cells} \mathrm{ml}^{-1}\right)$, over a period of $1000 \mathrm{~min}$. At various time points, aliquots of cell suspension, and aliquots of $\mathrm{NaOH}$ trap solution, were removed and tested for radioactivity associated with ${ }^{14} \mathrm{C}$ (see above).

TLC analysis. The cells were pelleted and $10 \mathrm{ml}$ of the supernatant was added to $3 \mathrm{ml}$ freshly prepared $1 \mathrm{mg}$ 2,4-dinitrophenylhydrazine $\mathrm{ml}^{-1}$ in $2 \mathrm{M} \mathrm{HCl}$, and the solution was incubated at $23^{\circ} \mathrm{C}$ for $48 \mathrm{~h}$. The solution was extracted with 3 vols ethyl acetate and the extract was dried. Authentic 2-hydroxypenta-2,4-dienoate, formed from allylglycine using L-amino acid oxidase (Collinsworth et al., 1973), and 4-hydroxy-2-oxo-valerate, synthesized as described by Dagley \& Gibson (1965), were derivatized in the same way. Extracts were dissolved in $200 \mu \mathrm{l}$ ethyl acetate, and spotted onto a Silica gel $60 \mathrm{~F}_{254}$ TLC plate (EM Science), which was then run in sec-butyl alcohol. Afterwards, a known quantity of a non-volatile ${ }^{14} \mathrm{C}$ compound was spotted on the plate as an internal reference and standard. The radioactivity and location of spots on the plate were quantified using a Molecular Dynamics Storm 840 phosphorimager, and Adobe Photoshop imaging software. Derivatives of 2-hydroxypenta-2,4dienoate and 4-hydroxy-2-oxovalate, as seen under visible or shortwavelength UV light, produced spots at $R_{\mathrm{F}}$ values of 0.54 and 0.36 , respectively.

Irradiation assays under non-growth conditions. $\left[{ }^{14} \mathrm{C}\right]$ Toluene was added to resting cells in $30 \mathrm{ml}$ crimp-top glass vials, which were sealed immediately with a teflon/butyl rubber insert. For irradiation, samples were placed symmetrically in a J. L. Shepherd and Associates model $143-45{ }^{137} \mathrm{Cs}$ irradiator producing $22 \mathrm{~Gy} \mathrm{~h}^{-1}$. At $28 \mathrm{~h}$, cells were harvested, and washed two times with $25 \mathrm{mM}$ sodium phosphate buffer, $\mathrm{pH} 7 \cdot 2$, containing $0 \cdot 2 \%$ fructose for $D$. radiodurans, 
or $0.85 \% \mathrm{NaCl}$ for $P$. putida F1. Small molecules were removed by three washes with ice-cold $10 \%$ trichloroacetic acid and the remaining pellet of macromolecules was counted for ${ }^{14} \mathrm{C}$ incorporation (Hanson \& Phillips, 1981).

GC-MS. Benzene, toluene, ethylbenzene or chlorobenzene $(45 \mu \mathrm{M})$ or $p$-xylene $(16 \mu \mathrm{M})$ was added to sealed vials containing $1 \mathrm{ml}$ resting $D$. radiodurans cells concentrated to an $\mathrm{OD}_{600}$ of $7 \cdot 5$ (approx. $1.5 \times 10^{9}$ cells $\mathrm{ml}^{-1}$ ). After $26 \mathrm{~h}$ shaking at $23^{\circ} \mathrm{C}$, samples were extracted and analysed by GC-MS on a Hewlett Packard 6890 gas chromatograph, as described previously (Lange et al., 1998). In parallel experiments, $D$. radiodurans $\mathrm{R} 1$ was shown not to oxidize any of the substrates tested.

Growth with toluene and fructose. D. radiodurans cells were initially grown in $50 \mathrm{ml}$ TYF broth at $21^{\circ} \mathrm{C}$ to an $\mathrm{OD}_{600}$ of 0.5 . After pelleting the cells, and washing them three times with $10 \mathrm{mM}$ sodium phosphate buffer, $\mathrm{pH} 7 \cdot 2$, cells were resuspended in $1 \mathrm{ml}$ of the same buffer. Resuspended cells $(100 \mu \mathrm{l})$ were used to inoculate $25 \mathrm{ml}$ basal minimal medium (Brim et al., 2003; Daly et al., 2004), or basal minimal medium supplemented with high concentrations of amino acids (rich minimal medium) (Venkateswaran et al., 2000) and containing 0 or $0.5 \%$ fructose. The medium was in $125 \mathrm{ml}$ flasks, to which toluene was introduced via vapour bulbs (Gibson et al., 1970) to maintain saturation. Flasks were shaken at 200 r.p.m. at $21^{\circ} \mathrm{C}$.

Preparation of sediment slurries. The most radioactive vadose sediments examined at DOE facilities have very low moisture contents (2-6\%) and are nutrient poor (Fredrickson et al., 1993). Uncontaminated subsurface $[81 \cdot 0-81 \cdot 5 \mathrm{ft}(24 \cdot 7-24 \cdot 8 \mathrm{~m})]$ sediments were obtained during coring of borehole 299-W22-48 in the $200 \mathrm{~W}$ area of the Hanford Site central plateau. Sediments were sieved to $<2 \mathrm{~mm}$, air-dried before use and prepared as slurries with Deinococcus minimal medium (Brim et al., 2003). Vadose sediments and coring techniques have been described previously (Fredrickson et al., 1993, 2004).

$\mathrm{Cr}(\mathrm{VI})$ reduction assays. $\mathrm{Cr}(\mathrm{VI})$ reduction was measured in suspensions of sediment. Samples were inoculated with cells to a final concentration of approx. $5 \times 10^{7} \mathrm{ml}^{-1}$. Sediment suspensions, consisting of $2 \mathrm{~g}$ sediment in $10 \mathrm{ml}$ basal minimal medium (i.e. without fructose or other carbon source) (Brim et al., 2003), in $25 \mathrm{ml}$ glass pressure tubes sealed with Teflon septa, were treated with gamma irradiation ( $35 \mathrm{kGy})$ and shown to be sterile, and then inoculated with cells, amended with $\mathrm{K}_{2} \mathrm{CrO}_{4}$ to $50 \mu \mathrm{M}$ and toluene $(100 \mu \mathrm{M})$ or fructose $(11 \mathrm{mM})$, where noted. The use of minimal medium enabled us to isolate the effects of carbon source on $\mathrm{Cr}(\mathrm{VI})$ reduction, while providing amino acids and micro-nutrients needed for survival (Venkateswaran et al., 2000). Suspensions were incubated at $30{ }^{\circ} \mathrm{C}$ for the indicated times under static conditions. $\mathrm{Cr}(\mathrm{VI})$ reduction was determined by measuring the loss of $\mathrm{Cr}(\mathrm{VI})$ from solution with time by mixing filtrates (pore size, $0 \cdot 2 \mu \mathrm{m}$ ) with sym-diphenylcarbizide reagent $(0 \cdot 25 \%$ in acetone) and measuring the absorbance of solutions at $540 \mathrm{~nm}$, as described previously (Fredrickson et al., 2000).

\section{RESULTS}

\section{Construction of toluene-mineralizing D. radiodurans}

Toluene-degradation functions encoded by $P$. putida (Aemprapa \& William, 1998; Harayama \& Rekik, 1990; Horn et al., 1991) (Fig. 1a) were introduced into D. radiodurans (ATCC BAA-816) chromosomal pS11 locus (Brim et al., 2000) as two distinct constitutively expressed gene cassettes (Fig. 1b, c). The integration of the todC1C2BADE genes within the $D$. radiodurans genome led to the construction of strain MD859, and a separate construction, which integrated the $x y l F J Q K$ genes, yielded strain MD883. In strain MD884, both gene cassettes were present. It is well established that tandem duplication expression vectors inserted into the pS11 locus are stably expressed and maintained in $D$. radiodurans in the absence of antibiotic selection, even during chronic irradiation (Brim et al., 2000; Lange et al., 1998), or after high-dose acute irradiation (Daly \& Minton, 1996). As expected, the presence of the tod and xyl cassettes (Fig. 1) did not affect resistance of $D$. radiodurans to irradiation (data not shown). In P. putida under aerobic conditions, TodC1C2BADE converts toluene to 2-hydroxy6-oxo-2,4-heptadienoate (Zylstra \& Gibson, 1989), and XylFJK converts 2-hydroxy-6-oxo-2,4-heptadienoate to acetate, pyruvate and acetaldehyde (Harayama \& Rekik, 1990; Horn et al., 1991); xylQ is present in the $x y l$ cassette and encodes an acetaldehyde dehydrogenase that converts potentially toxic acetaldehyde to acetyl-CoA (Aemprapa \& William, 1998).

\section{Functionality of the tod and $x y l$ cassettes in $D$. radiodurans}

Incubating resting cells (see above) of $D$. radiodurans strain MD884 (todC1C2BADE + xylFJQK) or P. putida F1 with uniformly ring-labelled $\left[{ }^{14} \mathrm{C}\right]$ toluene generated ${ }^{14} \mathrm{CO}_{2}$, with the yield from MD884 measured at approximately $60 \%$ that of P. putida F1 (Fig. 2a). During co-incubation, or individual incubations of strains MD859 (todC1C2BADE) and MD883 (xylFJQK) (Fig. 1), no significant levels of ${ }^{14} \mathrm{CO}_{2}$ were produced in the presence of $\left[{ }^{14} \mathrm{C}\right]$ toluene (Fig. 2a). These results indicate that strain MD884 functionally expresses the tod and $x y l$ genes because ${ }^{14} \mathrm{CO}_{2}$ is predicted to be generated following toluene catabolism to acetate, pyruvate and acetyl-CoA, through which ${ }^{14} \mathrm{C}$ can enter native Deinococcus intermediary metabolic pathways (Ghosal et al., 2005; Makarova et al., 2001; Venkateswaran et al., 2000). Other products of toluene biodegradation were also examined in engineered Deinococcus strains and $P$. putida $\mathrm{F} 1$ after incubating resting cells with labelled toluene. As expected, the ${ }^{14} \mathrm{C}$-label accumulated in non-volatile products for strains MD884, MD859 and P. putida F1, but not for MD883 or wild-type D. radiodurans (Fig. 2c). Because XylF (Fig. 1a) removes acetate from 2-hydroxy-6-oxo-2,4heptadienoate, a pathway truncated after XylF could result in some acetate-derived ${ }^{14} \mathrm{C}$ incorporation by the cell, ${ }^{14} \mathrm{CO}_{2}$ generation, and accumulation of 2-hydroxypenta-2,4-dienoate. Quantification of these radioactive intermediates using 2,4-dinitrophenylhydrazine derivation, and subsequent analysis via TLC and phosphorimaging, allowed comparison of their absolute radioactivities to the total radioactivity of the soluble degradation products. Of the total radioactivity derived from $\left[{ }^{14} \mathrm{C}\right]$ toluene as degradation products generated during incubation with MD884 (Fig. 2a), 1.4\% ended up in the 2-hydroxypenta-2,4-dienoate derivative, while the 

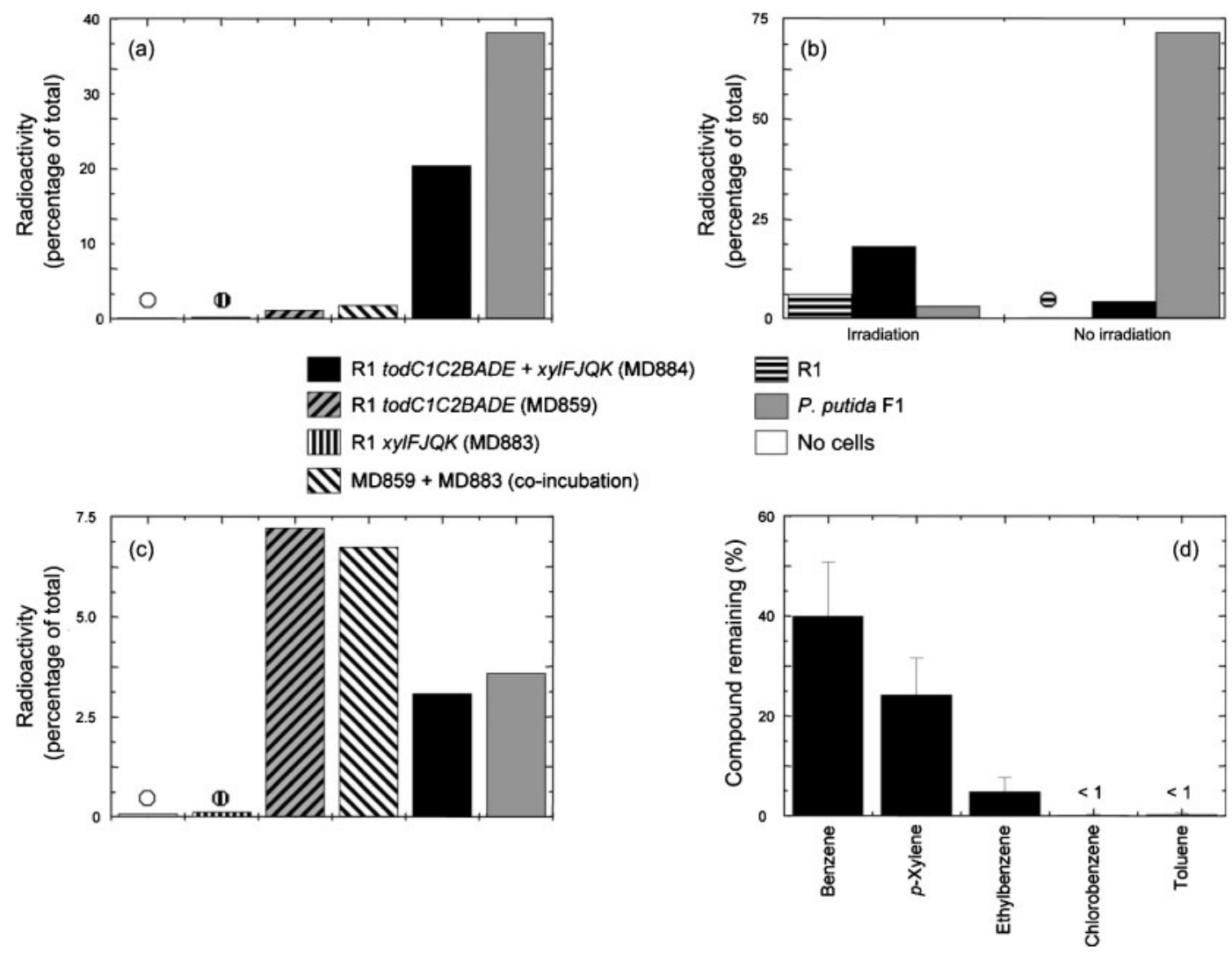

Fig. 2. Fate of $\left[{ }^{14} \mathrm{C}\right]$ toluene in engineered $D$. radiodurans (resting cells). (a) Generation of ${ }^{14} \mathrm{CO}_{2}$. (b) Incorporation into macromolecular cellular components with and without ionizing irradiation $\left({ }^{137} \mathrm{Cs}\left[\gamma, \beta^{-}\right]^{\mathrm{E}}, 23\right.$ Gy $\mathrm{h}^{-1}$ ). (c) Production of non-volatile radioactive products. (a) and (c) Cells were adjusted to an $\mathrm{OD}_{600}$ of 5.0 and assayed at $48 \mathrm{~h}$. (b) Cells were adjusted to an $\mathrm{OD}_{600}$ of $3 \cdot 5,\left[{ }^{14} \mathrm{C}\right]$ toluene added to $4 \cdot 1 \mu \mathrm{M}$, and assayed at $28 \mathrm{~h}$. (d) Transformation, assayed at $26 \mathrm{~h}$, of BTEX and chlorinated hydrocarbons by MD884 relative to $D$. radiodurans R1. Error bars indicate the standard deviation of three trials; (a), (b) and (c) a single replicate was made for each experimental point. When a column value is low, see inset circle for pattern designation and correspondence to key.

4-hydroxy-2-oxovalerate hydrazone contained $0 \cdot 1 \%$. These findings indicate that XylJ is functional, since the next intermediate in the pathway, 4-hydroxy-2-oxovalerate, was detected. The relatively small amount of 4-hydroxy-2oxovalerate in the resting cell medium suggests that 4hydroxy-2-oxovalerate is a transient product, and that the entire pathway is functional. Incubation of non-irradiated MD884 or P. putida $\mathrm{F} 1$ with $\left[{ }^{14} \mathrm{C}\right]$ toluene yielded ${ }^{14} \mathrm{C}$ incorporation into cell material, but no ${ }^{14} \mathrm{C}$ incorporation was detected in wild-type D. radiodurans (Fig. 2c). For nonirradiated MD884 incubations with $\left[{ }^{14} \mathrm{C}\right]$ toluene, substantial ${ }^{14} \mathrm{C}$ incorporation was detected in purified preparations of DNA, RNA, protein, lipids, and non-volatile small molecules (Table 1). In the presence of irradiation $\left({ }^{137} \mathrm{Cs}\left[\gamma, \beta^{-}\right]^{\mathrm{E}}\right.$, $\left.22 \mathrm{~Gy} \mathrm{~h}^{-1}\right),\left[{ }^{14} \mathrm{C}\right]$ toluene incorporation in $P$. putida $\mathrm{F} 1$ cellular components was reduced by $96 \%$. In contrast, strain MD884 showed a $60 \%$ increase in ${ }^{14} \mathrm{C}$-incorporation compared with non-irradiated MD884 cells (Fig. 2b). Radiation-stimulated incorporation of $\left[{ }^{14} \mathrm{C}\right]$ toluene into MD884 may be the result of radiation-induced oxygenation of toluene, which can produce $o-, m$ - and $p$-cresols
(Albarran \& Schuler, 2002). The three isomeric cresols were detected by GC-MS in irradiated buffer controls containing toluene (data not shown), consistent with oxygenation via

Table 1. Amount of ${ }^{14} \mathrm{C}$ incorporated into cellular fractions following incubation of resting cells (non-irradiated) with $9 \cdot 2 \mu \mathrm{M}$ [ring-UL- ${ }^{14} \mathrm{C}$ ]toluene [specific activity $56 \cdot 2 \mu \mathrm{Ci}$ $\mu_{\mathrm{mol}}{ }^{-1}\left(2 \cdot 08 \mathrm{MBq} \mu \mathrm{mol}^{-1}\right) ; 3.2 \times 10^{6}$ c.p.m.]

Results are for a single sample.

\begin{tabular}{|lccc|}
\hline \multirow{2}{*}{ Cell fraction } & \multicolumn{2}{c|}{ Radioactivity (percentage incorporation) } \\
\cline { 2 - 4 } & $\begin{array}{c}\text { D. radiodurans } \\
\text { R1 }\end{array}$ & MD884 & $\begin{array}{c}\text { P. putida } \\
\text { F1 }\end{array}$ \\
\hline DNA & $0 \cdot 01$ & $0 \cdot 20$ & $0 \cdot 30$ \\
RNA & $0 \cdot 08$ & $0 \cdot 80$ & $0 \cdot 40$ \\
Protein & $0 \cdot 02$ & $2 \cdot 2$ & $0 \cdot 90$ \\
Lipids & $0 \cdot 01$ & $0 \cdot 20$ & $0 \cdot 20$ \\
Small molecules & $0 \cdot 01$ & $0 \cdot 30$ & $0 \cdot 50$ \\
\hline
\end{tabular}


radiation-derived radicals, and they appear to be assimilated by MD884. It is possible that the cresols are oxidized to catechols, thereby becoming substrates for both cloned and naturally encoded catabolic genes (Lange et al., 1998). Thus, co-introduction of the tod and $x y l$ cassettes (Fig. 1) into D. radiodurans imparts the ability to mineralize toluene, and to utilize carbon derived from its catabolism for biosynthetic purposes, in the presence or absence of chronic radiation. GC-MS analysis confirmed the ability of MD884 to degrade toluene and the other prevalent fuel hydrocarbons benzene, ethylbenzene and $p$-xylene, as well as the chlorinated hydrocarbon chlorobenzene (Fig. 2d). A $255 \mu \mathrm{M}$ (approx. $24 \mathrm{mg}$ $1^{-1}$ ) toluene aliquot was rapidly metabolized by MD884 growing exponentially in rich medium, with concomitant generation of toluene-derived $\mathrm{CO}_{2}$. From a starting concentration $(255 \mu \mathrm{M}$ toluene) comparable to the highest reported in DOE mixed waste sites, about $50 \%$ of the toluene was removed in $15 \mathrm{~h}$ (Fig. 3). Thus, both resting (nutrient-depleted) MD884 (Fig. 2) and exponentially growing (nutrient-rich) MD884 (Fig. 3) are capable of utilizing toluene because the Tod and Xyl proteins are constitutively expressed in the engineered Deinococcus (Fig. 1).

\section{Growth studies with $D$. radiodurans strain MD884 (todC1C2BADE+xyIFJQK)}

MD884 grew at a similar rate, and to a final cell density, as did wild-type $D$. radiodurans $\mathrm{R} 1$, in TYF and minimal medium (Brim et al., 2003), and minimal medium supplemented with high concentrations of amino acids (enriched minimal medium) (Venkateswaran et al., 2000), with fructose as the carbon source. Without fructose, $D$. radiodurans MD884 inoculated into enriched minimal medium plus saturating toluene, supplied via vapour bulbs (Gibson et al., 1970), failed to grow (Fig. 4). When fructose was added to minimal medium, the rate and extent of growth were similar in both the presence and absence of toluene (Fig. 4). No significant lag phase was observed under the conditions used. In separate experiments without fructose, no growth was observed with toluene supplied to minimal medium cultures of strain MD884 using vapour bulbs, or via continuous sparging with toluene at approximately $1 \%$ of its vapour pressure at room temperature (data not shown).

\section{Chromate reduction by MD884 in toluene- supplemented sediment slurries}

Previously, $D$. radiodurans $\mathrm{R} 1$ has been shown to be capable of reducing toxic $\mathrm{Cr}(\mathrm{VI})$ to non-toxic $\mathrm{Cr}(\mathrm{III})$ under anaerobic or aerobic conditions coupled to the oxidation of lactate or pyruvate (Fredrickson et al., 2000). To isolate any toluene-derived benefit, we evaluated MD884 for its ability to aerobically reduce $\mathrm{Cr}(\mathrm{VI})$ to $\mathrm{Cr}(\mathrm{III})$ in slurries of natural sediment suspended in minimal medium. For $\mathrm{Cr}(\mathrm{VI})$ amended sediment samples, to which toluene was added, only those containing MD884 facilitated $\mathrm{Cr}(\mathrm{VI})$ reduction (Fig. 5). In parallel experiments, $\mathrm{Cr}(\mathrm{VI})$ was not reduced by MD884 in the absence of toluene. The amount of $\mathrm{Cr}(\mathrm{VI})$
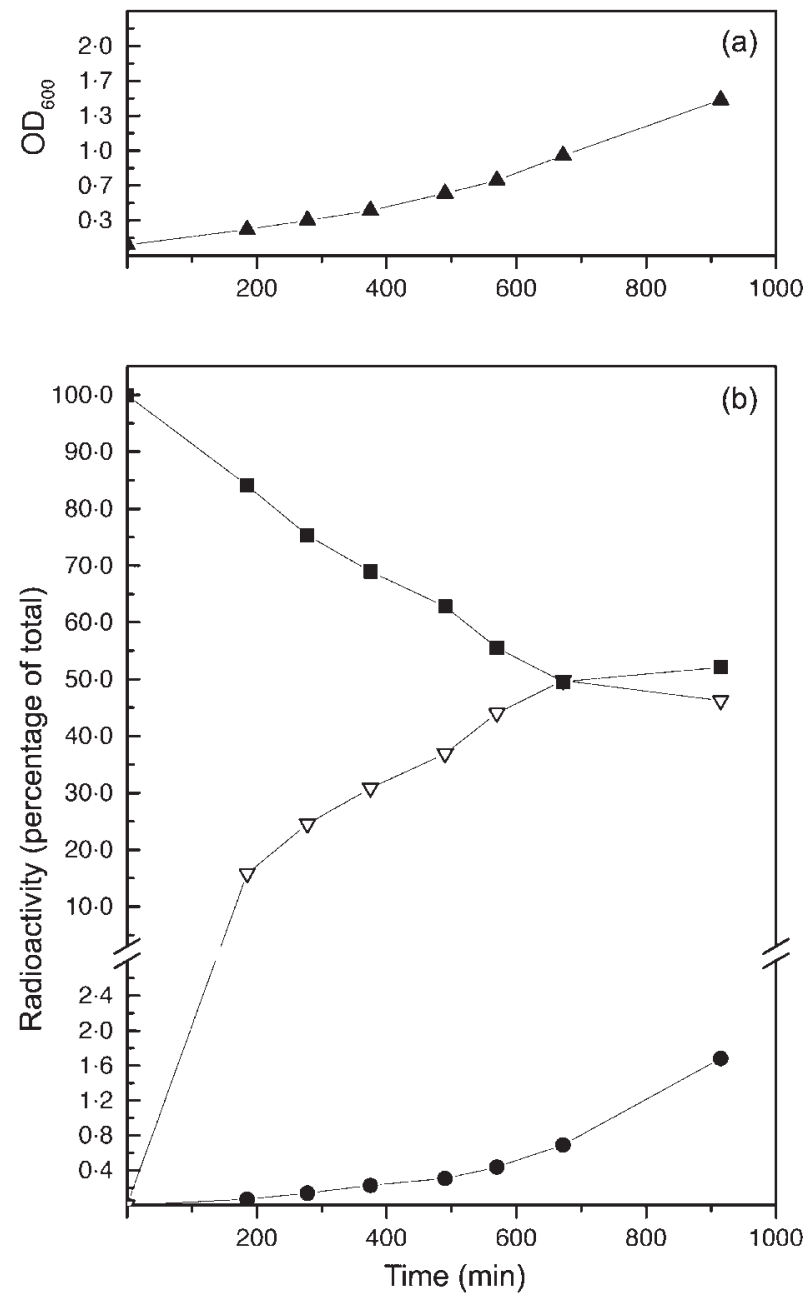

Fig. 3. Fate of $\left[{ }^{14} \mathrm{C}\right]$ toluene in engineered $D$. radiodurans strain MD884 growing in TYF. (a) Growth; (b) ${ }^{14} \mathrm{CO}_{2}$ generation ( $)$, non-volatile products formed $(\nabla)$ and $\left[{ }^{14} \mathrm{C}\right]$ toluene remaining (घ). A single replicate was made for each time point.

reduced in the presence of toluene was comparable with that previously obtained with $10 \mathrm{mM}$ lactate (Fredrickson et al., 2000).

\section{DISCUSSION}

We have previously expressed toluene dioxygenase (TDO) from $P$. putida $F 1$ in $D$. radiodurans, and shown that engineered cells incubated with ${ }^{14} \mathrm{C}$-labelled toluene in rich medium under chronic radiation yield toluene cisdihydrodiol (Lange et al., 1998); however, no ${ }^{14} \mathrm{CO}_{2}$, or intermediates that could be assimilated into cellular carbon, could be generated by this strain, and TDO did not confer the ability to derive energy from toluene oxidation. Rather, the TDO reaction itself consumed metabolic energy to produce toluene cis-dihydrodiol. Our goal of functionally coupling toluene oxidation with energy generation and biosynthetic processes of $D$. radiodurans was not achieved 


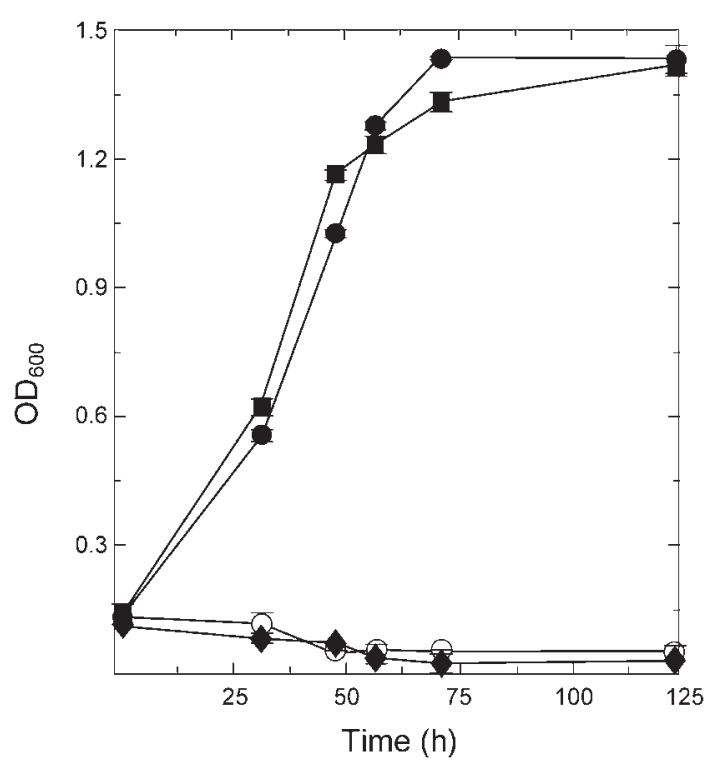

Fig. 4. Growth of MD884 with toluene and fructose. MD884 cells were inoculated into rich minimal medium with various combinations of fructose and toluene. Bars indicate the range of duplicate samples. - Saturating toluene $+0.05 \%$ fructose; $\boldsymbol{\square}$, no toluene $+0.05 \%$ fructose; $\bigcirc$, saturating toluene, no fructose; no toluene, no fructose.

because of uncertainties in design/engineering strategies relating to the metabolic configuration of $D$. radiodurans. Since then, we have shown that $D$. radiodurans has a functional TCA cycle, containing an active glyoxylate bypass needed for growth on acetate as a sole carbon/energy source (Ghosal et al., 2005; Lipton et al., 2002; Liu et al., 2003), that could be integrated with toluene oxidation. Importantly, pyruvate and acetate, the final products generated from the P. putida Tod and Xyl hybrid enzyme pathway (Harayama \& Rekik, 1990; Zylstra \& Gibson, 1989) selected for expression in D. radiodurans (Fig. 1), were shown to support moderate growth of D. radiodurans in minimal medium (Ghosal et al., 2005).

We constructed a $D$. radiodurans strain that constitutively expressed the genes todC1C2BADE and $x y l F J Q K$ integrated into the main chromosome (MD884, Fig. 1). Functional analysis of strain MD884 showed that it was able to mineralize toluene, and use carbon derived from its catabolism for cellular biosynthesis in the presence and absence of highlevel chronic radiation (Fig. 2) of the type $\left({ }^{137} \mathrm{Cs}\left[\gamma, \beta^{-}\right]^{\mathrm{E}}\right)$ that predominates at DOE waste sites (Fredrickson et al., 2004; Riley et al., 1992); in contrast, wild-type D. radiodurans, and engineered $D$. radiodurans strains containing either the todC1C2BADE or xylFJQK genes (Fig. 2a, b, c), could not. Furthermore, strain MD884 could degrade benzene, ethylbenzene, $p$-xylene and chlorobenzene (Fig. 2d). These results are another step towards the goal of broad-based utilization of engineered $D$. radiodurans strains for select waste environments, since toluene and related compounds inventoried in 1992 persist at hundreds of DOE radioactive waste sites (Riley et al., 1992).

As a minimum practical requirement for bioremediating a radioactive waste site with engineered $D$. radiodurans, the toluene-degrading functions (Fig. 1) need to function under complex nutrient conditions that support growth under chronic radiation (Venkateswaran et al., 2000). D. radiodurans strain MD884 exceeded this requirement for the following reasons. (i) Resting cells (Fig. 2), as well as cells growing in rich medium (Fig. 3), showed efficient degradation of toluene, and high levels of incorporation of carbon from $\left[{ }^{14} \mathrm{C}\right]$ toluene into cellular macromolecules; in comparison, toluene catabolism is strongly repressed in P. putida until other growth substrates are exhausted (Finette \& Gibson, 1988). (ii) In slurries of sediment in minimal medium, only MD884 reduced $\mathrm{Cr}(\mathrm{VI})$ when toluene was added as the sole carbon/energy source (Fig. 5). These results demonstrate that strain MD884 may have utility for the reduction of metals coupled to organic contaminant oxidation in aerobic radionuclide-contaminated sediments, with or without the addition of growth-promoting nutrients (biostimulation) (McCullough et al., 2003). The microbial enzymic reduction of multivalent metals and radionuclides can profoundly diminish their solubility and toxicity. Thus, D. radiodurans strain MD884 provides a possible microbiological mechanism for detoxifying radioactive waste sites co-contaminated with $\mathrm{Cr}(\mathrm{VI})$ and toluene (Riley et al., 1992; McCullough et al., 2003).

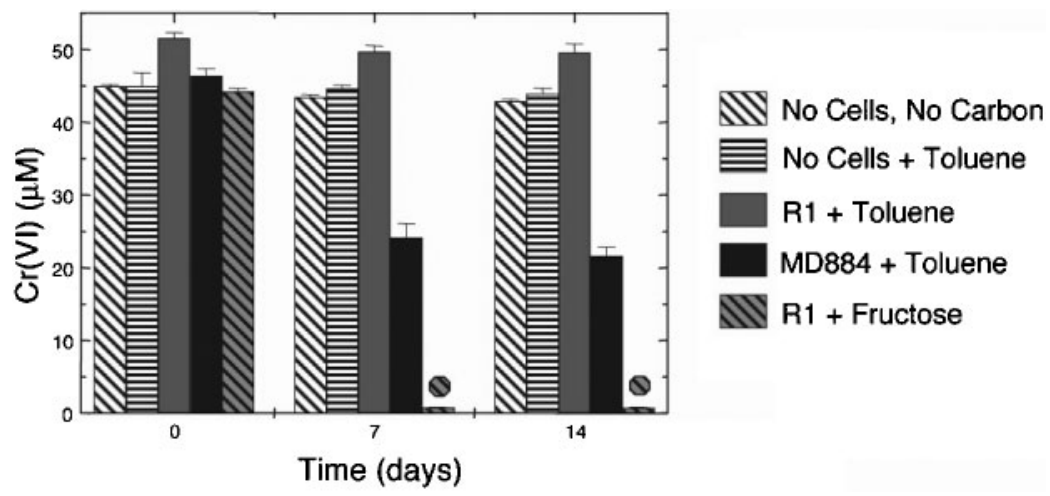

Fig. 5. $\mathrm{Cr}(\mathrm{VI})$ reduction by $D$. radiodurans strain MD884 in sediment suspensions. Error bars indicate the standard deviation of three trials. 
The failure of strain MD884 to grow on toluene as the sole carbon/energy source (Fig. 4) underscores some of the difficulties in re-engineering metabolism, as observed previously. Recombinant strains carrying genes encoding a heterologous pathway may fail to express all the genes (Watts et al., 2004), but the present study confirmed that most metabolic intermediates, and $\mathrm{CO}_{2}$, were produced, indicating that the failure to grow must be due to other reasons. In other examples, bacteria engineered for 2-chlorotoluene (Haro \& de Lorenzo, 2001) or cyclohexene metabolism (Swift et al., 2001) expressed complete pathways, yet failed to grow, perhaps because of metabolic misrouting. Causes underlying the failure to grow can be subtle: a quinone oxidoreductase is required for growth of a Pseudomonas strain on terpenes, although the direct physiological role of this enzyme in the metabolism is unclear (Forster-Fromme \& Jendrossek, 2005). Since D. radiodurans MD884 grew normally in the presence of fructose as the carbon source in the presence of toluene (Fig. 3 and 4), metabolite toxicity associated with toluene degradation appears to be unlikely (Lange et al., 1998). Further, toluene was transformed into cellular macromolecules (Table 1) and $\mathrm{CO}_{2}$ (Fig. 2 and 3), suggesting that metabolic misrouting within the recombinant pathway of MD884 was also not a problem. Instead, as indicated by the limited mineralization of toluene (Fig. 2a), the yield of pyruvate and acetate from the Tol/Xyl pathways might be insufficient to sustain levels of TCA-cycledependent energy production needed for growth.

While $\mathrm{O}_{2}$ concentrations in sediments are variable $(0-$ $400 \mu \mathrm{M})$ (Smith, 1995), they are typically high enough to support Tod/Xyl functions (Costura \& Alvarez, 2000). There are only two oxygen-dependent enzymes in the Tol/Xyl pathway: catechol-2,3-dioxygenase, which has a $K_{\mathrm{m}}$ for $\mathrm{O}_{2}$ of $17 \mu \mathrm{M}$ (Kukor \& Olsen, 1996); and toluene dioxygenase, for which the $K_{\mathrm{m}}$ for $\mathrm{O}_{2}$ is likely to be near $4 \cdot 3 \mu \mathrm{M}$, as reported for the closely related benzoate-1,2-dioxygenase (Yamaguchi \& Fujisawa, 1980). However, it should be noted that bacterial isolates from deeper radioactive unsaturated soil at Hanford [e.g. depth $84 \mathrm{ft}(25.60 \mathrm{~m}) ; 21 \mu \mathrm{Ci}$ $\left.(777 \mathrm{kBq}){ }^{137} \mathrm{Cs}\left[\gamma, \beta^{-}\right]^{\mathrm{E}}(\mathrm{g} \text { soil })^{-1}\right]$ have been shown to comprise predominantly Gram-positive aerobic chemoheterotrophs (Balkwill et al., 1997; Fredrickson et al., 2004). Even in deep environments where $\mathrm{O}_{2}$ concentrations could become limiting, bioventing and biosparging strategies could be applied as part of a biostimulation approach to help overcome $\mathrm{O}_{2}$ limitations (Werner et al., 1997).

The development of viable in situ bioremediation applications is a long-term goal of the DOE, including the use of engineered organisms (McCullough et al., 2003), and a variety of DOE field-research efforts are currently under way (McCullough et al., 2003). Genetically engineered micro-organisms have already been used successfully in non-DOE regulatory-agency-approved field-scale bioremediation (Ripp \& Sayler, 2002; Strong et al., 2000). Recombinant organisms have been considered as an option when naturally occurring organisms do not provide the complete suite of functions needed to deal with contaminant mixtures and sites. D. radiodurans is non-pathogenic, and indigenous to some contaminated DOE sites (Fredrickson et al., 2004). In the present example of metabolically engineered $D$. radiodurans metabolizing radioactive, heavy metal and organic contaminant mixtures to reduce their toxicity and/or migration in the environment, strain MD884 is a possible candidate for future research with contaminated sediments in situ or ex situ.

\section{ACKNOWLEDGEMENTS}

This research was funded by the DOE (Office of Biological and Environmental Research) grant DE-FG02-04ER63918 from the Environmental Remediation Sciences Program. Pacific Northwest National Laboratory is operated for the DOE by Battelle Memorial Institute under Contract DE-AC06-76RLO 1830.

\section{REFERENCES}

Aemprapa, S. \& William, P. A. (1998). Implications of the $x y l Q$ gene of TOL plasmid pWW102 for the evolution of aromatic catabolic pathways. Microbiology 144, 1387-1396.

Albarran, G. \& Schuler, R. H. (2002). Micellar electrophoretic capillary chromatographic analysis of the products produced in the radiolytic oxidation of toluene and phenol. Radiat Phys Chem 63, 661-663.

Balkwill, D. L., Reeves, R. H., Drake, G. R., Reeves, J. Y., Crocker, F. H., Baldwin-King, M. \& Boone, D. R. (1997). Phylogenetic characterization of bacteria in the subsurface microbial culture collection. FEMS Microbiol Rev 20, 201-216.

Brim, H., McFarlan, S. C., Fredrickson, J. K., Minton, K. W., Zhai, M., Wackett, L. P. \& Daly, M. J. (2000). Engineering Deinococcus radiodurans for metal remediation in radioactive mixed waste environments. Nat Biotechnol 18, 85-90.

Brim, H., Venkateswaran, A., Kostandarithes, H. M., Fredrickson, J. K. \& Daly, M. J. (2003). Engineering Deinococcus geothermalis for bioremediation of high-temperature radioactive waste environments. Appl Environ Microbiol 69, 4575-4582.

Collinsworth, W. L., Chapman, P. J. \& Dagley, S. (1973). Stereospecific enzymes in the degradation of aromatic compounds by Pseudomonas putida. J Bacteriol 113, 922-931.

Costura, R. K. \& Alvarez, P. J. (2000). Expression and longevity of toluene dioxygenase in Pseudomonas putida F1 grown at different dissolved oxygen concentrations. Water Res 34, 3014-3018.

Dagley, S. \& Gibson, D. T. (1965). The bacterial degradation of catechol. Biochem J 95, 466-474.

Daly, M. J. (2000). Engineering radiation-resistant bacteria for environmental biotechnology. Curr Opin Biotechnol 11, 280-285.

Daly, M. J. \& Minton, K. W. (1996). An alternative pathway of recombination of chromosomal fragments precedes recA-dependent recombination in the radioresistant bacterium Deinococcus radiodurans. J Bacteriol 178, 4461-4471.

Daly, M. J., Gaidamakova, E. K., Matrosova, V. Y. \& 10 other authors (2004). Accumulation of $\mathrm{Mn}(\mathrm{II})$ in Deinococcus radiodurans facilitates gamma-radiation resistance. Science 306, 1025-1028.

Eary, L. D. \& Rai, D. (1987). Kinetics of chromium (III) oxidation to chromium (VI) by reaction with manganese dioxide. Environ Sci Technol 21, 1187-1193. 
Finette, B. A. \& Gibson, D. T. (1988). Initial studies on the regulation of toluene degradation by Pseudomonas putida F1. Biocatalysis 2, 29-37.

Forster-Fromme, K. \& Jendrossek, D. (2005). Malate:quinone oxidoreductase $(\mathrm{MqoB})$ is required for growth on acetate and linear terpenes in Pseudomonas citronellolis. FEMS Microbiol Lett 246, 25-31.

Fredrickson, J. K., Brockman, F. J., Bjornstad, B. N. \& 7 other authors (1993). Microbiological characteristics of pristine and contaminated deep vadose sediments from an arid region. Geomicrobiol J 11, 95-107.

Fredrickson, J. K., Kostandarithes, H. M., Li, S. W., Plymale, A. E. \& Daly, M. J. (2000). Reduction of Fe(III), Cr(VI), U(VI), and Tc(VII) by Deinococcus radiodurans R1. Appl Environ Microbiol 66, 20062011.

Fredrickson, J. K., Zachara, J. M., Balkwill, D. L., Kennedy, D., Li, S. M., Kostandarithes, H. M., Daly M, J., Romine, M. F. \& Brockman, F. J. (2004). Geomicrobiology of high-level nuclear waste-contaminated vadose sediments at the Hanford site, Washington state. Appl Environ Microbiol 70, 4230-4241.

Ghosal, D., Omelchenko, M. V., Gaidamakova, E. K. \& 10 other authors (2005). How radiation kills cells: survival of Deinococcus radiodurans and Shewanella oneidensis under oxidative stress. FEMS Microbiol Rev 29, 361-375.

Gibson, D. T., Hensley, M., Yoshioka, H. \& Marby, T. J. (1970). Formation of (+)-cis-2,3-dihydroxy-1-methylcyclohexa-4,6-diene from toluene by Pseudomonas putida. Biochemistry 9, 1626-1630.

Hanson, R. S. \& Phillips, J. A. (1981). Manual of Methods for General Bacteriology. Washington, DC: American Society for Microbiology.

Harayama, S. \& Rekik, M. (1990). The meta cleavage operon of TOL degradative plasmid pWW0 comprises 13 genes. Mol Gen Genet 221, 113-120.

Haro, M. A. \& de Lorenzo, V. (2001). Metabolic engineering of bacteria for environmental applications: construction of Pseudomonas strains for biodegradation of 2-chlorotoluene. J Biotechnol 85, 103-113.

Horn, J. M., Harayama, S. \& Timmis, K. N. (1991). DNA sequence determination of the TOL plasmid (pWWO) xylGFJ genes of Pseudomonas putida: implications for the evolution of aromatic catabolism. Mol Microbiol 5, 2459-2474.

Hugouvieux-Cotte-Pattat, N., Kohler, T., Rekik, M. \& Harayama, S. (1990). Growth-phase-dependent expression of the Pseudomonas putida TOL plasmid pWW0 catabolic genes. J Bacteriol 172, 6651-6660.

Kukor, J. J. \& Olsen, R. H. (1996). Catechol 2,3-dioxygenases functional in oxygen-limited (hypoxic) environments. Appl Environ Microbiol 62, 1728-1740.

Lange, C., Wackett, L. P., Minton, K. W. \& Daly, M. J. (1998). Engineering a recombinant Deinococcus radiodurans for organopollutant degradation in radioactive mixed waste environments. Nat Biotechnol 16, 929-933.

Lipton, M. S., Pasa-Tolić, L., Anderson, G. A. \& 18 other authors (2002). Global analysis of the Deinococcus radiodurans proteome using accurate mass tags. Proc Natl Acad Sci U S A 99, 11049-11054.

Liu, Y., Zhou, J., Omelchenko, M. V. \& 12 other authors (2003). Transcriptome dynamics of Deinococcus radiodurans recovering from ionizing radiation. Proc Natl Acad Sci U S A 100, 4191-4196.

Lovley, D. R. \& Coates, J. D. (1997). Bioremediation of metal contamination. Curr Opin Biotechnol 8, 285-289.

Macilwain, C. (1996). Science seeks weapons clean-up role. Nature 383, 375-379.

Makarova, K. S., Aravind, L., Wolf, Y. I., Tatusov, R. L., Minton, K. W., Koonin, E. V. \& Daly, M. J. (2001). Genome of the extremely radiation-resistant bacterium Deinococcus radiodurans viewed from the perspective of comparative genomics. Microbiol Mol Biol Rev 65 , $44-79$.

McCullough, J., Hazen, T. C., Benson, S. M., Blaine-Metting, F. \& Palmisano, A. C. (2003). Bioremediation of Metals and Radionuclides, 2nd edn. Germantown, MD: US Department of Energy, Office of Biological and Environmental Research.

Omelchenko, M. V., Wolf, Y. I., Gaidamakova, E. K., Matrosova, V. Y., Valisenko, A., Zhai, M., Daly, M. J. \& Makarova, K. S. (2005). Comparative genomics of Thermus thermophilus and Deinococcus radiodurans: divergent routes of adaptation to thermophily and radiation resistance. BMC Evol Biol 5, 57-79.

Riley, R. G., Zachara, J. M. \& Wobber, F. J. (1992). Chemical Contaminants on DOE Lands and Selection of Contaminant Mixtures for Subsurface Science Research. Washington, DC: US Department of Energy, Office of Energy Research, Subsurface Science Program.

Ripp, S. \& Sayler, G. S. (2002). Field release of genetically engineered microorganisms (GEM). The Encyclopedia of Environmental Microbiology, pp. 1278-1287. New York: Wiley.

Saier, M. H., Jr (2005). Beneficial bacteria and bioremediation. J Mol Microbiol Biotechnol 9, 63-64.

Smith, R. L. (1995). Manual of Environmental Microbiology, pp. 577-585. Washington, DC: American Society for Microbiology.

Strong, L. C., McTavish, H., Sadowsky, M. J. \& Wackett, L. P. (2000). Field-scale remediation of atrazine-contaminated soil using recombinant Escherichia coli over-expressing atrazine chlorohydrolase. Environ Microbiol 2, 91-98.

Sugden, K. D., Campo, C. K. \& Martin, B. D. (2001). Direct oxidation of guanine and 7,8-dihydro-8-oxoguanine in DNA by a high-valent chromium complex: a possible mechanism for chromate genotoxicity. Chem Res Toxicol 14, 1315-1322.

Swift, R. J., Carter, S. F., Widdowson, D. A., Mason, J. R. \& Leak, D. J. (2001). Expression of benzene dioxygenase from Pseudomonas putida ML2 in cis-1,2-cyclohexanediol-degrading pseudomonads. Appl Microbiol Biotechnol 55, 721-726.

Timmis, K. N., Steffan, R. J. \& Unterman, R. (1994). Designing microorganisms for the treatment of toxic wastes. Annu Rev Microbiol 48, 525-557.

Venkateswaran, A., McFarlan, S. C., Ghosal, D., Minton, K. W., Vasilenko, A., Makarova, K. S., Wackett, L. P. \& Daly, M. J. (2000). Physiologic determinants of radiation resistance in Deinococcus radiodurans. Appl Environ Microbiol 66, 2620-2626.

Wackett, L. P., Sadowsky, M. J., Newman, L. M., Hur, H.-G. \& Li, S. (1994). Metabolism of polyhalogenated compounds by a genetically engineered bacterium. Nature 368, 627-629.

Watts, K. T., Lee, P. C. \& Schmidt-Dannert, C. (2004). Exploring recombinant flavonoid biosynthesis in metabolically engineered Escherichia coli. Chembiochem 5, 500-507.

Werner, F. T., Walters, J. E. \& Keefer, G. B. (1997). Bioventing pilot test results at the low point drain area, Offutt AFB, Nebraska. Ann NY Acad Sci 829, 313-325.

White, O. J., Eisen, A., Heidelberg, J. F. \& 28 other authors (1999). Complete genome sequencing of the radioresistant bacterium Deinococcus radiodurans R1. Science 286, 1571-1577.

Yamaguchi, M. \& Fujisawa, H. (1980). Purification and characterization of an oxygenase component in benzoate 1,2-dioxygenase system from Pseudomonas arvilla C-1. J Biol Chem 255, 5058-5063.

Zylstra, G. J. \& Gibson, D. T. (1989). Toluene degradation by Pseudomonas putida F1. Nucleotide sequence of the todC1C2BADE genes and their expression in Escherichia coli. J Biol Chem 264, 14940-14946. 